\title{
The relation between increased carotid intima-media thickness with fibrin monomers in obese children
}

\author{
Esra Yazarlı ${ }^{1}$, Rukiye Saç$^{2}$, Betül Şimşek ${ }^{3}$, Özlem Engiz ${ }^{3}$, Bulent Alioglu ${ }^{3}$, and Yildiz \\ Dallar $^{2}$ \\ ${ }^{1}$ Mustafa Kemal Universitesi Tayfur Ata Sokmen Tip Fakultesi \\ ${ }^{2}$ Sağlık Bakanlığı Ankara Eğitim ve Araştırma Hastanesi \\ ${ }^{3}$ Saglik Bakanligi Ankara Egitim ve Arastirma Hastanesi
}

January 22, 2021

\begin{abstract}
Objective: This study aimed to investigate the association between carotid intima-media changes that play a part in the atherosclerotic process in childhood obesity and fibrin monomers as an important indicator of fibrin plaque. Methods: This is a cross-sectional study of obese children and non-obese healthy control subjects. Height, weight, body mass index, waist/hip ratio, systolic/diastolic blood pressures were recorded, in addition, biochemistry, hemogram, fibrin monomers and d-dimer were measured in both groups. Right and left common carotid intima-media thicknesses were measured by ultrasonography and mean carotid intima-media thickness was calculated. Results: Obese children ( $\mathrm{n}=89,46.1 \%$ girls, median age: $12.6 \pm 2.3$ years) and healthy control group ( $\mathrm{n}=40,52.5 \%$ girls, median age: $13.2 \pm 2.2$ years) were comparable in terms of gender, age and puberty stage. Mean carotid intima-media thickness was higher in obese children than the healthy control group ( $p=0.002)$. There was no difference between the two groups in terms of fibrin monomers and D-dimer levels. In obese children, there was a weak negative correlation between mean carotid intima-media thickness and fibrin monomers $(\mathrm{p}=0.030, \mathrm{r}=-0.233)$. Conclusion: In obese children, mean carotid intima-media thickness was determined higher, as an early indicator of atherosclerosis. We want to emphasize that obese children are at risk for cardiovascular disease and should be evaluated in terms of atherosclerosis. This study investigates the relation between increased carotid intima-media thickness and fibrin monomers, in children, the first time in Literature. What's already known about this topic? It is possible to reveal the early period of the atherosclerosis process by showing carotid intima medial thickness. Fibrin is a major component of many atherosclerotic plaques. What does this article add? Our study investigated the relationship between mean carotid intima-media thickness in childhood obesity and fibrin monomers. But no positive correlation was found between fibrin monomers and the carotid intima-media thickness.
\end{abstract}

\section{Hosted file}

title page.pdf available at https://authorea.com/users/391087/articles/505265-the-relationbetween-increased-carotid-intima-media-thickness-with-fibrin-monomers-in-obese-children

\section{Hosted file}

MA \selectlanguage\{polish\} $\dot{I} \backslash$ selectlanguage\{english\}N TEXT.pdf available at https://authorea. com/users/391087/articles/505265-the-relation-between-increased-carotid-intima-mediathickness-with-fibrin-monomers-in-obese-children

\section{Hosted file}

Tables.pdf available at https://authorea.com/users/391087/articles/505265-the-relationbetween-increased-carotid-intima-media-thickness-with-fibrin-monomers-in-obese-children 